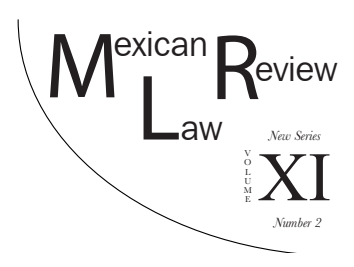

\title{
POPULAR GONSTITUTIONALISM AND FORMS OF DEMOCRACY
}

\author{
Jaime Gárdenas Gracia*
}

ASTRACT: This article describes the crisis of representative democracy, and the need to bolster modalities of direct, participatory, deliberative and communitarian democracy in order to overcome the rift between the governed and the government. A brief overview of some current constitutional models underlines the fact that critical and popular modes of constitutionalism are absent in Mexico. The conclusion of the article evaluates and critiques the instruments of direct and communitarian democracy that were inscribed into Mexico City's recently approved local Constitution.

Keywords: Popular constitutionalism, critical constitutionalism, new Latin American constitutionalism, crisis of representative democracy, Mexico City Constitution.

Resumen: El ensayo expone la crisis de la democracia representativa y, la necesidad de fortalecer las modalidades de democracia directa, participativa, deliberativa y comunitaria para superar el divorcio gobernantes-gobernados. Se realiza un breve repaso de algunos modelos constitucionales vigentes y se pone de manifiesto que las propuestas críticas y populares son inexistentes en el constitucionalismo federal mexicano. Finalmente se hace una crítica a los instrumentos de democracia directa y comunitaria aprobados en la reciente Constitución local de la Ciudad de México.

Palabras Clave: Constitucionalismo popular, constitucionalismo crítico, nuevo constitucionalismo latinoamericano y crisis de la democracia representativa.

* Researcher at the Institute of Legal Research at the Autonomous National University of Mexico, UNAM. Email: jaicardenas@gmail.com. 


\section{Table of Gontents}

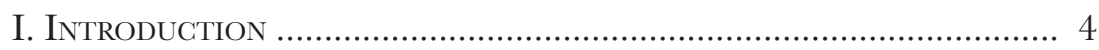

II. Gurrent Constitutional Models: the Role of Popular Constitutionalism ....

III. The Forms of Participatory and Community Democracy Needed to Transcend Representative Democracy.

IV. The Unsuccessful Efforts at Direct and Communitarian Democracy in the Recent Mexico Gity Constitution.

V. Conclusions.

\section{INTRODUCTION}

A specter is haunting the world, the specter of a crisis of representative democracy. Citizens do not feel represented by parties, nor do they believe that representative institutions are geared towards guaranteeing human rights or democracy. There is a deep fissure between those who govern and those who are governed, and this gap, by some accounts, is responsible for the rise of populist movements. But it is mistaken to view populism merely as a response to a crisis of representation in politics. A South American theorist explains it thus:

The crisis of representation in politics is a necessary but not a sufficient condition of populism. A complete picture of the situation needs to include another factor: a crisis in the upper echelons where a new form of leadership is emerging and gaining ground as it convincingly presents itself as an alternative leadership that is distinct from the existing political class. This is the form of leadership which most effectively takes advantage of the palpable crisis of representation and it does so by articulating unsatisfied demands, political resentment, feelings of marginalization, and with a discourse that unifies these elements with a reconfiguration of political space through the introduction of an additional institutional crevice. ${ }^{1}$

Beyond the question of whether the global crisis in representative democracy produces populism, it is certain that there is a problem with representative democracy, and that institutional design, including that of Mexico, is embedded in this issue as it is at the center of these principles and characteristics. For these reasons, I am convinced that the solution must include a far-reaching and thorough review of the mechanisms and institutions of this form of democracy, and that merely proposing adjustments to this framework is insufficient. We must ask, for instance, why the most important decisions of

\footnotetext{
1 Juan Garlos Torre, La audacia y el cálculo, 145 (Sudamericana, Buenos Aires) (2011).
} 
a polity - those related to the current economic model - are not voted upon by citizens. Or, for example, why free trade agreements or security agreements between Mexico and the United States are not decided through a referendum or a consultation with citizens.

In many representative democratic regimes, the political system allows for the concentration of mass media, especially electronic media, in very few hands, which leads to a deficit of social and political representation. TV and radio licenses, for example, are generally granted to those who are close to big business interests. Once the licensees begin operations they are not bound to air a diversity of news items, rather they tend to reproduce the point of view of those in power. Such a political system cannot fully guarantee the right to information, and thus cannot be considered democratic.

Anotherwayin which the politicalsystem is manipulated is throughcampaign finance. In countries such as the United States, where private campaign contributions exceed public ones, campaign donors, many of which are large corporations, donate money to some candidates rather than others, once their candidate reaches public office, be it Congress or some other institution, he or she will tend to represent the interests of donors over those of citizens. ${ }^{2}$ As Ian Shapiro has stated in reference to US democracy, the competitive Schumpeterian system has been substituted by money, and the competition for votes is substituted by competition for donations and campaign spending, leading to a bipartisan domination of electoral institutions and a political model that is ultimately anti-competitive and anti-pluralist. ${ }^{3}$

Another instrument of manipulation of the political system is lobbying in Congress and in other instances of government: powerful economic interests have the resources to ensure professional lobbyists permanently guide and supervise the design of public policy and legislation. In countries such as Mexico, where there is vast inequality, manipulation in favor of the powerful within the political system is carried out through: vote buying and vote coercion; the clientelist use of public programs (the manipulation of poverty for electoral gain); the staffing of electoral management bodies to favor oligarchic interests; the use of government budgets to influence electoral outcomes, taking advantage of weak oversight; the preservation of unaccountable spaces outside of the legal control of the state, where de facto powers are protected; the undercutting of direct, participatory, deliberative and procitizen democracy; and the inhibition of the exercise of economic, social,

2 The US Supreme Court's 2010 decision in the case of Citizens United v. Federal Election Commission is well known. In this case, the effect of the Supreme Court ruling was to approve the constitutionality of unlimited campaign spending by the country's largest corporations - private donations with no limits - couched in the argument that this furthered corporate and union's capacity for "freedom of expression".

3 Ian Shapiro, El Estado de la teoría democrática 207 (Bellaterra, Barcelona) (2005). 
cultural, and environmental rights, thereby not addressing or remedying the causes of poverty. ${ }^{4}$

These shortcomings of representative democracy, along with many others, persist in several countries, which from our point of view demonstrates that representative democracy must go through a comprehensive transformation so that politics can link citizen and rulers. Under the current iteration of representative democracy, far removed from citizens with high levels of corruption and impunity, it is evident that this system no longer serves the purposes its creators had in mind when they designed it and put it to practice.

\section{Gurrent Constitutional Models: the Role of Popular Constitutionalism}

Every constitution is guided by a theoretical model and influenced by the politics of its time. In Mexico, at present, it is evident that the influences of neoliberal globalization and certain traditional positivist influences are behind structural constitutional reforms. However, important contemporary theoretical influences are absent, save for traces of neo-constitutionalism, which appear as a consequence of the constitutional reform in human rights published in Mexico's Official Federal Gazette on June 10, 2011. There is no strong neo-constitutionalist influence in the Mexican Constitution, nor is there evidence of the influence of critical or popular constitutionalism. Influences of new Latin American constitutionalism are also absent.

The most influential versions of constitutionalism in our time are neoconstitutionalism, critical constitutionalism, popular constitutionalism and new Latin American constitutionalism. It is important to reflect on each of these strands and to define their contours to understand if any of these could become an avenue to stand up to the negative consequences of neoliberal globalization.

Neo-constitutionalism or contemporary constitutionalism, both in its continental European and its Latin American form, has a deep Anglo-Saxon inspiration - drawing on Ronald Dworkin, for example - and has encouraged criticism and examination of the traditional theses of positivism. ${ }^{5}$ In this view, the constitution re-materializes the body of laws, that is, it implies a hierarchy of values that condition the validity of the norms in the constitution. The constitution is thus the immediate and direct origin of rights and obligations, and is not limited to being the primal origin of the national legal system. The thesis of separation between law and morality cannot be held

4 Jaime Cárdenas Gracia, La crisis del sistema electoral mexicano. A propósito del PROCESo ELECTORAL DE 2012 (IIJ-UNAM, México) (2014).

5 Miguel Carbonell, Teoría del neoconstitucionalismo. Ensayos escogidos (Miguel Carbonell ed., Trotta, Madrid) (2007). 
to be true in absolute terms because the constitution has incorporated the values of justice into its principles. The legislator is no longer the voice of the sovereign, because he or she must adapt their actions to the constitution. In this view, the principle of legality gives way to a principle of judiciality and constitutionality. ${ }^{6}$ Interpretation and application of the law have been modified by the inclusion of constitutional principles, as well as the weight of rhetorical argumentation is couched in the logical-formal argumentation of Rights. ${ }^{7}$ Constitutional norms do not have the classical structure of legal rules and, hence, are not tenable to being subsumed, or to the application of logical syllogisms. This, however, should not lead to total and arbitrary reliance on the decisions of judges, but rather points to the need for judges to adequately justify their rulings based on varied argumentation techniques, according to theories such as those espoused by Viehweg, Perelman, Toulmin, MacCormick, Alexy, Aarnio, Peczenik, and so on.

Following Guastini, neo-constitutionalism has the following salient characteristics: 1) constitutional rigidity; 2) control of the constitutionality of laws; 3) the binding strength of the constitution; 4) the over-interpretation of the constitution; 5) the direct application of the constitution by judges; 6) interpretation according to the constitution; ${ }^{8}$ and finally, 7) the direct influence of the constitution over political relations. ${ }^{9}$ In neo-constitutionalism, the interpretation from and through the constitution and treaties is of such importance that it is at the center of legal and constitutional theory. ${ }^{10}$ Constitutional judges in continental Europe and Latin America have therefore acquired a surprisingly salient role that has on many occasions displaced that of elected legislators.

Constitutional principles have transformed traditional legal interpretation by stimulating new forms of legal reasoning. The use of the principle of proportionality and the configuration of cases in open instead of closed modalities has also contributed to this transformation. The test of proportionality forces the interpreter to develop a material or substantive rationality that is far more complex than legal subsumption, a rationality closer to moral argumentation. Argumentation based on principles forces the interpreter to use standards of interpretation whose ends place the judge's discretion in a position similar to that which Kelsen or Hart had envisioned.

6 Gustavo Zagrebelzky, El Derecho dúctil. Ley, Derechos, Justicia 144-153 (Trotta, Madrid, 2008) (1993).

7 Manuel Atienza, Las razones del derecho. Teorías de la argumentación jurídica 32 (Centro de Estudios Constitucionales, Madrid) (1991).

8 This refers to interpretación conforme, which is a method of interpreting the law in constant reference to the constitution. It is sometimes referred to as conforming interpretation in English.

9 Riccardo Guastini, La constitucionalización del ordenamiento jurídico: el caso italiano, in Neoconstitucionalismo(s) 49-57 (Trotta, Madrid, 2003).

10 Luis Rodolfo Vigo, Interpretación constitucional 81-104 (editorial Abeldeo-Perrot, Buenos Aires) (1993). 
The constitutional reform on human rights in Mexico, published on June 10, 2011 in the Official Federal Gazette, is clearly influenced by neo-constitutionalism, as is made clear by the fact that it includes the obligation for all authorities to carry out interpretation in accordance to the Constitution along with pro homine interpretation (second paragraph of Article 1 of the Constitution). This influence is also clear in the third paragraph of Article 1 of the Constitution which refers to the methods and criteria of interpretation in fundamental rights: interdependence, universality, indivisibility and progressivity. The same could be said about the ruling of the Supreme Court corresponding to record 912/2010 (the case of Rosendo Radilla), which includes the diffuse control of constitutionality and conventionality for all authorities in the country, as well as the ruling to resolve contradicting theses 293/2011 which established with definitive clarity the concepts of Constitutional Block and the Parameter of Constitutional Regularity.

This shift in judicial culture means that the constitutional transformations I have just mentioned imply that some judicial methods and arguments - such as systematic argument or those derived from the principles of interpretation and argumentation - could acquire a far more important role than that which they have traditionally held in the everyday life of authorities and judges. This could also be the case with the use of methods and arguments that arise from the law of treaties, including the link between domestic tribunals and the rulings of supranational bodies. In this vein, we find the ex officio constitutional interpretation, which allows courts and authorities to analyze, independently from what the parties have argued, whether the secondary laws that they are about to apply have constitutional and conventional bases and, therefore, if these laws can be disapplied or expelled from the system, or if authorities should proceed with an interpretation according to the constitution, having explored beforehand whether these laws are constitutional and conventional or not.

This is innovative and important for law because it constitutionalizes and conventionalizes every judicial rule in order to protect and guarantee human rights. There are, however, some shortcomings. Alterio's contributions help us identify these shortcomings: 1) the judge, especially the constitutional judge, is given a surprisingly important role, above other established powers, including the legislature; 2) the constitutional judge lacks genuine democratic legitimacy as the members of high courts in any country are not elected by citizens (with the exception of Bolivia); 3) the constitutional judge is often designated by majority political forces in one of the houses of congress, and thus reproduces status quo conceptions which are an extension of the main political forces; 4) the constitutional judge represents the elitist conceptions of society, as they themselves come from an elite group; 5) the neo-constitutionalist model distrusts popular participation and believes, along with Ferrajoli and Dworkin, that human rights are not up for democratic debate, while at the same time human rights are treated as trump cards in decision making, and 
are a reserved domain; 6) electoral democracy is substituted for what is called substantial democracy - that of human rights and principles - which subordinates political democracy; 7) constitutional control and conventionality is placed above the will of the majority; 8) politics is subordinated to the constitution, international treaties and interpretation; 9) human rights form part of an objective morality that exists beyond the will of people and therefore cannot be limited by majority decisions; and finally, 10) neo-constitutionalism has an undeniable natural law basis. ${ }^{11}$

The neo-constitutionalist model has attracted many and, to the extent that, as in Ferrajoli's theory, there is a proposal to spread constitutionalism around the world in order to counterbalance the noxious elements of neoliberal globalization. However, this model is primarily based on legal theories that are anchored to the scheme of the nation state, which have not yet expanded to include the complexities of the new rights in a globalized world. Additionally, and this may be what is most pernicious to new planetary conditions, these theories rely on an elitist model of law and of democracy which is often opaque because the majority of citizens are uninformed about the reasons and the processes of the courts' decisions or of the motives that politicians had to accept international agreements and treaties which are not voted on by referenda. In other words, neo-constitutionalist theories that adopt a call to constitutional democracy lack democratic elements founded on participation and citizen deliberation. ${ }^{12}$ Neo-constitutionalist theories are conceptual schemes that give certain unelected officials who are beyond citizen control the power to define what is and what is not a human right and what scope these rights will have.

Critical perspectives influenced by or originating in Marxism, such as the school of the alternative use of the law, ${ }^{13}$ or critical legal studies, ${ }^{14}$ have long posited that: 1) the law is used ideologically by its operators in order to defend dominant classes and interests; and 2) there is a historical and instrumental role of the law which contributes to the maintenance of the status quo, and therefore, there is a need to use critical postulates in order to turn the law into an instrument capable of bringing social transformations.

11 Ana Micaela Alterio, Corrientes del Constitucionalismo contemporáneo a debate, 8 RevisTa Problema. Anuario de Filosofía y Teoría del Derecho 227-306, January-December (2014).

12 Carlos de Gabo Martín, Pensamiento crítico. Constitucionalismo crítico (Trotta, Madrid) (2014).

13 Nicos Poulantzas, Marx y el Derecho moderno, in Hegemonía y dominación en el estado moderno, (Cuadernos de Pasado y Presente, Buenos Aires, Siglo XXI) (1975). Umberto CErroni, Introducción al pensamiento político (Siglo XXI, México) (1994). Nicolás López Calera, et al., Sobre el uso alternativo del derecho (Fernando Torres Editor, Valencia) (1975).

14 Duncan Kennedy, Libertad y restricción en la decisión judicial (Universidad de los Andes, Pontificia Universidad Javeriana, Ediciones Uniandes, Instituto Pensar, Siglo del Hombre Editores, 1999) (1997). 
From these critical perspectives, the judicial superstructure appears not simply as a reflection of a structure or an instrument, it is also a body that allows for the general and contextual conditions for the existence of the structure itself. In this sense, the law is an expression of the contradictions of the worldwide struggles of social class and, even though it generally upholds the interests of the dominant classes, it may also benefit subordinate classes by imposing conditions on the structure and in the mechanisms of the state, including on local apparatuses. There is no unanimity among those who espouse critical perspectives on the law, among them are pessimists who believe that the law can never aid the weak; while there are others who consider that law - both as theory and as judicial practice - can become an essential tool for class emancipation. In this sense, critical theories have much to contribute to the construction of an alternative to neo-constitutional theories, especially weak ones. ${ }^{15}$

Popular constitutionalism has been sustained mainly by currents originating in North America which have had a major impact in Latin America, and in South America in particular. ${ }^{16}$ The distinctive features of popular constitutionalism are: 1) it makes the constitution more flexible and can even exceed it; 2) it challenges judicial supremacy and in certain cases can refute any form of judicial control over constitutionality; 3) it suggests an extrajudicial interpretation of the constitution; 4) it calls for the democratization of all economic and political institutions; and 5) it seeks to recover the relationship between the law and politics. ${ }^{17}$ Among the most salient ends of this theoretical current lies in challenging the role of constitutional judges as the monopolistic and maximum interpreter of the constitution and of the body of laws, ${ }^{18}$ as well as in promoting citizen participation in collective decisions to the fullest, as the democratic legitimacy of these decisions depends on the degree of participation they emanate from. ${ }^{19}$

Critical legal studies and popular constitutionalism are dynamic and thus constantly changing. According to these approaches, citizens should participate in the process of making and defining the law, and judicial control of the

15 Angélica M. Bernal, The Meaning and Perils of Presidential Refounding in Latin America, Constellations. An International Journal of Critical and Democracy, 21, 4, New York (2014). Federico Finchelstein, Returning Populism to History, Constellations. An International Journal of Critical and Democracy, 21, 4, New York (2014). Yannis Stavrakakis, The Return of the People: Populism in the Shadows of the European Crisis, Constellations. An International Journal of Critical and Democracy, 21, 4, New York (2014).

16 Roberto Gargarella, Roberto, Acerca de Barry Friedman y el "constitucionalismo popular mediado", Revista Jurídica de la Universidad de Palermo, 6 -1, Buenos Aires, 2005.

17 Ana Micaela, Alterio Corrientes del Constitucionalismo contemporáneo a debate, 8 REVISTA PROBLEMA. ANUARIO DE FILOSOFÍA Y TEORÍA DEL DERECHO 254-255, January-December (2014).

18 Larry D. Kramer, Constitucionalismo popular y GONTrol DE CONSTitucionalidad (Paola Bergallo, Marcial Pons trans., Madrid, 2011) (2004).

19 Mark Tushnet, Taking the Constitution Away from the Courts (Princeton University Press) (1999). 
laws should be done away with and replaced by citizen control. The authors who defend these positions are well aware of the 'risks' of popular participation: fascism, anti-intellectualism, the persecution of unpopular minorities, the exaltation of mediocrity and the romantic exaggeration of the virtues of the masses. ${ }^{20}$ Nevertheless, these scholars believe that only the people can provide legitimacy to governments, and that fear of society or of majorities contributes to the maintenance of the status quo.

The purpose of the law is to promote the rules of majorities and other forms of citizen participation and deliberation to guarantee that the institutional structures and the definitions of human rights today depend on society, and not on an enlightened elite of constitutional judges who represent the interests of the status quo. ${ }^{21}$ Popular constitutionalists are divided between those who argue that the United States Supreme Court's important decisions should be reviewed by that country's congress, and those who posit that the constitutional review of fundamental issues - such as the unconstitutionality of laws or general norms - should be carried out by the people themselves. ${ }^{22}$

Popular constitutionalists have put forth various proposals for U.S. law in order to promote citizen participation in the definition of human rights. These proposals include: 1) promoting constitutional reform procedures; 2) electing, through the popular vote, supreme court justices; 3) investing citizens and certain popular powers with the capacity to review Supreme Court decisions; 4) allowing for popular revocation of Supreme Court justices; and 5) social disobedience of judicial decisions. ${ }^{23}$ These measures are founded on the axiomatic, and not only the technical, principle of majority rule, as well as on the constitutional importance of popular sovereignty as origin and objective of norms and institutions, on the importance of deliberating public issues, and on the idea that the democratic process must define the meaning and scope of the law, including human rights.

Popular constitutionalism does not develop notions, concepts or categories that challenge the pernicious elements of the law in neoliberal globalization. Despite this important gap, it does include elements that are absent in neoconstitutionalism, namely the emphasis on the role of citizens to define the law and to ultimately determine the content of human rights. The insistence in popular constitutionalism on democratizing institutions and the law, although confined by its parameters (the nation state), can easily be expanded

20 Jack M. Balkin, Populism and Progressivism as Constitutional Categories, PAPER 268, FACUlty SchOLARSHIP SERIES 1950-1951 (1995).

21 Roberto Gargarella and Roberto Niembro Ortega, Constitucionalismo progreSISTA: Retos y Perspectivas. Un homenaje a MARK Tushnet (UNAM-Instituto de Estudios Constitucionales del Estado de Querétaro) (2016).

22 Roberto Post and Reva Siegel, Reva, Popular Constitutionalism, Departamentalism, and Judicial Supremacy, 92 California Law Review (2004).

23 Roberto Post and Reva Siegel, Reva, Popular Constitutionalism, Departamentalism, and Fudicial Supremacy, 92 California Law Review 1039 (2004). 
to a global scale. If we accept that there are possibilities of expanding constitutionalism around the world, then this expansion must include citizen participation and deliberation in national societies as well as in global society. Globalizing, neoliberal law can only be unmasked by the democratic legitimacy that citizens bestow through their participation in public affairs, and it is their power that can limit the interests of large transnational corporations as well as shedding light on these interests.

The new Latin American constitutionalism, which focuses on theorizing around the Constitutions of Venezuela (adopted in 1999), Ecuador (2008), and Bolivia (2009), has some sordid elements, as well as some enlightening ones. Chief among its most deplorable aspects is the promotion of hyperpresidentialism. Among its positive aspects, we find that the new Latin American constitutionalism: 1) seeks to build more equal societies ${ }^{24}{ }^{2}$ ) broadens the mechanisms of participatory democracy; 3) presents democratic means to construe constitutional controls; 4) recovers the state's role in the national economy as a means to lessen economic and social inequalities; and finally 5) argues for an international integration that is more just something that is affirmed in different latitudes. ${ }^{25}$ This is a constitutionalism wherein the constituent will of the popular classes finds expression in vast social and political mobilization, creating a bottom-up constitutionalism, whose protagonists are those that have been marginalized together with their allies. ${ }^{26}$ These protagonists seek to expand the field of the political beyond the liberal horizon through a new form of conceiving institutions (a plurinational approach), a new form of territoriality (asymmetric autonomies), a new legality (judicial pluralism), a new political regime (intercultural democracy) and new individual and collective subjectivities (individuals, communities, nations, peoples, nationalities), in which constitutional changes aspire to implement anti-capitalist and anti-colonial policies. ${ }^{27}$

24 Roberto Gargarella, El nacimiento del constitucionalismo popular, in TEORÍA Y CRÍTICA DEL Derecho constitucional 249-262 (Abeledo Perrot, tome I, Buenos Aires, 2008).

25 Roberto Viciano Pastor and Rubén Martínez Dalmau, Aspectos generales del nuevo constitucionalismo latinoamericano, in El NUEvo CONSTITUCIONALISMO EN AMÉRICA LATINA 9-43 (Corte Constitucional, Quito, 2010).

26 This work distinguishes between formal and material characteristics of the new Latin American constitutionalism. Among its formal characteristics, the authors point out that new texts have the following traits: 1) they incorporate new legal categories that old Latin American constitutionalism did not consider; 2) they put forth a new notion of unconstitutionality based on the emergence of new government offices and institutions; 3) they are lengthier constitutions; 4) they are more complex constitutions; and finally 5) they are constitutions that reestablish the role of the state in the economy, that is, they are anti-neoliberal.

27 Boaventura de Sousa Santos, Refundación del Estado en América Latina. PerSPECTIVAs DESDE unA EPISTEMOlogía del Sur 85 (Universidad de los Andes, Siglo del Hombre Editores y Siglo XXI, México, Guatemala and Buenos Aires 2010) (2009). 
New Latin American constitutionalism promotes broad means of direct, participatory and deliberative democracy, including the recognition of the right to resist and of intercultural democracy. It frees the constitution from the bounds that international treaties signed before the drafting of the new constitution. It is a theory that is weary of the elitist powers of constitutional courts, and therefore, attempts to mitigate the power of these organs through participatory mechanisms. In the constitution there are specific criteria to guide constitutional interpretation and thus avoid judicial discretion, ${ }^{28}$ in some cases, class actions against supposed unconstitutional provisions are established so that citizens, without having to prove a specific form of procedural legitimacy, can argue for the unconstitutionality of certain issues in constitutional courts. ${ }^{29}$

Furthermore, new Latin American constitutionalism reaffirms national sovereignty over the legal interests of neoliberal globalization. In this way, nations can recover control over their natural resources, with an insistence on the re-nationalization of resources which were once privatized, and a demand to ensure that nation states exploit these resources to the benefit of national societies. In this sense, new Latin American constitutionalism re-establishes the possibility of national control of the national economy in order to promote material equality among citizens. It is a constitutionalism that is respectful to, and protective of, the culture of native peoples. For these reasons, some constitutions, such as Bolivia's, enshrine the plurinational nature of the state. There are also fundamental rights included in the Bolivian Constitution that are of Indigenous origin such as the right to Madre Tierra (Mother Earth) and the right to buen vivir (living well). These are constitutions that promote many forms of cooperation and solidarity among peoples, through the promotion of self-management, cooperative management, cooperatives, popular savings accounts, and community corporations.

The democratic theory of new Latin American constitutionalism acknowledges different forms of democratic deliberation that respect Indigenous peoples and their cultures. It therefore accepts different criteria of democratic representation, recognizing the fundamental collective rights of peoples as a condition for the exercise of individual rights, broadening the catalogue of fundamental rights to include social and identity rights, and maintaining that education should be compatible with the distinct cultures within a country in order to purge neocolonialist elements. In the politics of new Latin American constitutionalism, it is popular sovereignty that determines the scope of the constitution and of human rights.

28 Garlos Villabella, Nuevo constitucionalismo latinoamericano. ¿Un nuevo paraDigma? (Grupo Editorial Mariel, Instituto de Ciencias Jurídicas de Puebla, A.C., Universidad de Guanajuato, Juan Pablos Editor) (2014).

29 Ana Micaela Alterio and Roberto Niembro Ortega, ¿Qué es el constitucionalismo popular? Una breve referencia al uso de las fuerzas armadas en México como fuerzas de seguridad, in Constitucionalismo popular en Latinoamérica 178 (Porrúa, México, 2013). 
There are, without a doubt, criticisms to be made of the new Latin American constitutionalism, as I have mentioned, it has fostered hyper-presidentialism in Latin America. But it should nonetheless be taken seriously as a means to confront the damaging consequences of neoliberal globalization. The alternative nature of new Latin American constitutionalism, its insistence on material equality, its emphasis on the rights of Indigenous peoples, the promotion of the recovery of different forms of democratic participation, the defense of natural resources so that they may be used to benefit the nation, the economic command of the nation state, the broadening of social and collective rights that is unheard of in western law, and the espousal of a politics of solidarity and cooperation in the face of neoliberalism's possessive individualism, are all qualities that make this form of constitutionalism a powerful instrument to transcend the negative and deeply entrenched elements of neoliberal globalization which are expressed in weak neo-constitutionalism.

\section{The Forms of Participatory and Community Democracy Needed to Transcend Representative Democracy}

The potential of participatory democracy in Brazil has been studied by Leonardo Avritzer and Boaventura de Sousa Santos, among others. ${ }^{30}$ For these authors, participatory democracy implies handing permanent power to citizens in moments between elections - as well as during elections - so that they can participate at these times in deciding fundamental matters of the state. Namely, by permanently supervising or monitoring through referenda, proposing constitutional and legal reforms, carrying out citizen audits, or suggesting public policies through legislative initiatives.

These instruments of direct, participatory democracy challenge social exclusion and seek to combat poverty through mechanisms in which citizens decide the priorities of fundamental government choices and public budgets. Citizen participation has numerous positive consequences: 1) it allows citizens to become involved permanently in public affairs (not only during elections), thus legitimizing the political system and the decisions which are taken by and because of society; 2) it allows for the redistribution of wealth through the prioritization of social issues in the budget; 3 ) it unites the governed with the government; 4) it aides the fight against corruption through instruments of citizen control; 5) it can be reconciled with representative democracy. There are forms of combining participatory and representative democracy, for example through the coexistence of representative democracy at a national or centralized level with participatory elements at the local level. Another form is through the government's recognition of participatory proceduralism,

30 Leonardo, Avritzer, Modelos de deliberación democrática: un análisis del presupuesto participativo en Brasil, in Democratizar la Democracia. Los CAminos de la Democracia PARTicipativa (Fondo de Cultura Económica, México, 2004). 
whereby public forms of monitoring and public deliberation can substitute part of the process of representation and traditional deliberation. ${ }^{31}$

In addition to the forms of participation already mentioned, there are mechanisms within the tradition of direct democracy such as referenda, popular legislative initiatives, citizen consultations, motions to repeal from office, citizen class actions arguing for unconstitutionality, among others. These mechanisms can mitigate popular anger, limit political corruption and, most importantly, allow the voices of those who are generally excluded to be heard. ${ }^{32}$ The purpose of participatory democracy is to avoid the exclusion of citizens, and to emphasize citizen participation through means other than political parties. Its instruments limit the unacceptable consequences of any representative system based exclusively on political parties: elitism, a closedoff group of political elites, and the lack of transparency in deliberation and in public affairs.

If what are referred to in Latin America as delegative democracies are not corrected, there will be no full-fledged democracies, even if these delegative 'democracies' have relatively fair elections and political parties, parliaments and the media that enjoy freedoms and courts which block anti-constitutional policies. When citizens are not treated as people in practice, if their decisions are delegated to others, if they only participate through the vote and afterwards have no opportunity to verify or evaluate the work that elected officials carry out, and if the offices responsible for horizontal accountability do not function properly, there is a huge loss of legitimacy in the political system. ${ }^{33}$ For these reasons, participation must be incentivized both through semi-direct mechanisms, as well as through the use of techniques such as those described by de Sousa Santos, Avritzer, and other authors. We must assume that it is the right of citizens to evaluate whether their government has satisfied their needs and requirements, and that only citizens are capable of doing so, as they know more than their governments do about their own necessities. Participation, therefore, is a corrective to the deficiencies of traditional representative democracy.

The deliberation of public issues is a fundamental element of advanced democracies. As Joshua Cohen has argued, deliberative democracy implies a framework of social and institutional conditions that allow for free discussion among equal citizens, providing the necessary conditions for free participation, association and expression..$^{34}$ Deliberative democracy requires that the

\footnotetext{
31 Adela Cortina, Ética del discurso y democracia participativa, 112 January, Revista Sistema 25-40 (1993).

32 Thomas E. Cronin, Direct Democracy: The Politics of Initiative, Referendum and Recall, 126-226, (Cambridge University Press) (1989). Martín Krause and Margarita Molteni, Democracia directa (Abeledo-Perrot, Buenos Aires) (1997).

33 Guillermo O’Donnell, Delegative Democracy, 5,1, Journal of Democracy (1994).

34 Joshua Cohen, Procedimiento y sustancia en la democracia deliberativa, 4, 14, April/June, Metapolítica, 29 (2000).
} 
authorization to exercise power comes as the consequence of permanent discussion through an architecture of dispositions that guarantees responsibility and accountability on behalf of those who exercise public power, not only through elections - though elections are important - but rather through procedures whereby public issues are made known through publicity, legislative work is supervised, and the work of other branches of the state is monitored by citizens.

In deliberative democracy, democracy is not reduced merely to a process of political aggregation through the vote and elections, rather it involves a process of public debate that competes with the political systems over the prerogative of political decision. ${ }^{35}$ This dispute intends to broaden the practice of democracy. Where does deliberative democracy originate? In its contemporary incarnation, it comes from Habermas's work, which advanced the very important concept of the public sphere. ${ }^{36}$ The public sphere is a place for the free interaction of groups, associations and social movements, and it requires the possibility of a critical-argumentative relation with politics. For deliberative democracy to work, several elements must be in place: a) deliberative processes need to be carried out argumentatively, that is, through the regulated exchange of information and reason between equals that present and critically examine various points of view; b) deliberations must be inclusive and public, no one, in principle, must be excluded and all those that could be possibly affected by the decisions should have the same opportunity to join the discussion; c) deliberations must be free from external coercion, participants are sovereign to the degree that they are related to the requirements of communication and to the processual rules of debate; d) deliberations should be free from any internal coercion that may affect the equality of participants, as each as the same opportunity to be heard, introduce issues, make contributions, suggest and criticize proposals; e) deliberations must seek, in general, an agreement that is rationally motivated and that can be, in principle, carried out without restrictions or taken up at any moment; f) political deliberations must conclude by contrasting the majority's decision, while this examination is based on the notion that the fallible opinion of the majority can be considered a reasonable base for a common practice until a minority convinces the majority otherwise; $g$ ) political deliberations must encompass every issue susceptible to being regulated, in particular the issues that are relevant, taking into account the interest of all; h) political deliberations should be carried out around the interpretation of the needs and transformations of pre-political

\footnotetext{
35 Leonardo Avritzer, Teoría democrática, esfera pública y deliberación, 4, 14, April/June, Metapolítica, 86 (2000).

36 Jürgen Habermas, Facticidad y validez. Sobre el derecho y el Estado democrático DE DERECHO EN TÉRminos DE TEORÍA DEL Discurso 363 (Trotta, Madrid, 1998) (1992).
} 
preferences; i) the absence of public deliberations must lead to the nullification of judicial acts and to the imposing of sanctions on public servants. ${ }^{37}$

Deliberative democracy recognizes that the rule of the majority does not guarantee impartiality, rather a decision that is supported by a majority but not by all of those involved in a conflict can indeed be partial. Nor is unanimity an ideal, because it requires making decisions within a specific timeframe: unanimity as an exclusive rule would lead to the defense of the status quo. According to Nino, because the rule of the majority and the rule of unanimity are insufficient, there must be other elements such as: 1) the knowledge of the interests and needs of others, which implies the inclusion of every part of society in the public deliberation so that individuals have the opportunity to make decisions according to ordered preferences and rankings; 2) the need to avoid exclusively presenting naked, egoistic interests to others, and instead to present interests, needs, and preferences in an argumentative framework which continuously justifies each point of view; 3) the discussion with others should contribute to the detection of empirical and logical errors, as it is common for some to commit the same error as others; 4) the necessity for participants to put themselves in the shoes of others, understanding not only their interests but also their emotions, which implies possessing the intellectual faculty of imagination and the attribute of empathy; 5) the attribute of consensus beyond mere negotiation, conducted on the basis of pure interest; and finally, 6) the collective tendency towards impartiality derived from decisions made through a process of inclusive participation and deliberation. ${ }^{38}$

Representative democracy does not correspond to a deliberative scheme, ${ }^{39}$ for this reason Habermas argued in favor of a model of deliberation similar to that set forth in the preceding paragraphs. He defined deliberative politics in two ways: the formation of a democratically constituted will in institutional spaces, and the construction of an informal opinion in extra-institutional spaces. According to Habermas, the possibility of legitimate government arises through the interrelation of these two spaces. ${ }^{40}$

In this sense, the crisis is based on a system of representation, which must be corrected. Some suggest that representation should be conceived as a form of delegation which allows for the continued discussion from a point of view that was reached by the electorate during the debates that led up to the election of representatives at every level of political decision making: government, parliament, and judiciary. It is important to avoid delegating

37 Jürgen Habermas, Facticidad y validez. Sobre el Derecho y el Estado democrático DE DERECHO EN TÉRMINOS DE TEORÍA DEL DISCURSo 382-383 (Trotta, Madrid, 1998) (1992).

38 Carlos Santiago Nino, La constitución de la democracia deliberativa, 166-180 (Gedisa Editorial, serie Filosofía del Derecho, Barcelona) (1997).

39 Antonio Porras Nadales, Representación y democracia aVanzada (Cuadernos y Debates 50, Centro de Estudios Constitucionales, Madrid) (1994).

40 Jürgen Habermas, Facticidad y validez. Sobre el derecho y el Estado democrático DE DERECHO EN TÉRMINOS DE TEORÍA DEL Discurso 407 and ff. (Trotta, Madrid, 1998) (1992). 
this mandate to representatives, so that the people themselves can discuss in a direct manner what is to be done. Political parties can help materialize a deliberative vision if they have democratic processes in their structures and if they are organized around ideological positions, value systems and models of society, and not based purely on economic or social group interests. The representative system demands the highest possible inclusion of sectors and people, and for these reasons it is unjustifiable to exclude those who have committed a crime from the political process. Also, the representative system must be modified in its four classical stages of the process - debate, mandate, control, and governmental action - so as to broaden its deliberative and participatory components. ${ }^{41}$ If the rules of open government are not complied with, the consequence should be the legal annulment of decisions taken by the authorities and a termination of the duties of said authorities.

I have argued elsewhere ${ }^{42}$ for the necessity of a direct, participatory and deliberative democracy that is different from that which exists today in many countries in the world, which is characterized by elitism. ${ }^{43}$ The participativedeliberative model underlines the control of the representative by the represented as well as public and open deliberation of affairs, where citizens can take part in many of the decisions made by authorities. Deliberation implies a serious and attentive weighing of reasons in favor and against a given proposal; it is a process in which individuals study the reasons for and against given courses of action. ${ }^{44}$ Deliberation and participation foster a set of virtues in citizens as well as in the model itself. Cognitive biases are remedied, as knowing that there is a problem does not automatically lead to an attempt to address it. For example, in the United States, an all-white jury may lack the necessary information to understand the conduct of a Hispanic mother, as practical wisdom is not only a matter of having good information, but also of having the sensitivity to weigh said information. Virtue is instilled and increased, for that which is not known cannot be demanded, such as what happens to women living in oppressive patriarchal regimes who cannot demand a more equitable position, as true equity would require knowledge of part of a society they do not have access to.

The deliberative model fosters citizen participation, it brings politicians closer to citizens, creates accountability, and informs the public about the

41 Antonio Porras Nadales, Representación y democracia aVanzada (Cuadernos y Debates 50, Centro de Estudios Constitucionales, Madrid) (1994).

42 Jaime Cárdenas Gracia, El modelo participativo y deliberativo, 11 Cuestiones Constitucionales. Revista Mexicana de Derecho Constitucional, IIJ-UNAM (2004). Jaime Cárdenas Gracia,

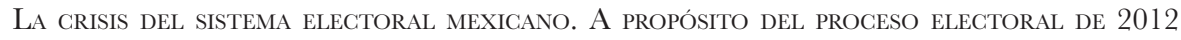
(UNAM, México) (2014).

43 Félix Ovejero, Democracia liberal y democracias republicanas, 111 April, Claves de Razón Práctica, 18-30 (2001).

44 James D. Fearon, La deliberación como discusión, in LA DEMOCRACIA DELIBERATIVA 88 (Editorial Gedisa, Barcelona, 2001) (1998). 
reasons why legislators have taken certain decisions and not others. It also includes citizens in decision-making processes, and so allows them to determine the degree of justification that each point of view requires, and to gauge the normative dimension of each decision at every step in its development. This approach clearly incorporates citizens into the public sphere and provides education in civic virtues. Additionally, the deliberative model allows for the legal nullification of decisions by authorities when they are not a product of deliberation, and creates mechanisms to hold authorities to account for decisions of this nature.

Communitarian democracy implies the recognition of the individual and collective human rights of Indigenous peoples. ${ }^{45}$ It centers on acknowledging their autonomy, which is the means to ensure that they may exercise their political, social, economic, legal, cultural, territorial and environmental rights in an independent fashion. Indigenous peoples have the right to self-determination, which is to say, to freely define their political and legal conditions, and to freely set the course for their economic, social and cultural development. They also enjoy the right to free, prior and informed consent on all issues that impact them as established by Article 6 of the International Labour Organization's Convention 169.

Communitarian democracy implies establishing territories with forms of self-government in the locations where indigenous peoples live. The outline of these territories must be made in keeping with the history, culture, society and identity of Indigenous peoples, as well as in their will, as expressed in an assembly or consultation. In Mexico, there has long been a demand for the recognition of Indigenous peoples as subjects and entities of public rights, with a legal character and formally recognized estates, so that they may exercise autonomous forms of political and administrative organization. This recognition has not been fully established, despite the 2001 reform to Article 2 of the Mexican Constitution.

Communitarian democracy thus refers to the self-government of peoples, founded upon the expression of the will of the majority of the population through plebiscites and consultations that are organized according to customs and traditions. Governments, authorities and representatives of Indigenous peoples must be elected according to their own normative systems and procedures.

A comprehensive democracy - representative, direct, participative, deliberatie and communitarian - must be established as a precondition of the constitutional state, it is not enough for representative and electoral democracy to simply make smaller adjustments along the way. Without active participation by citizens and social movements that goes beyond voter turnout, there is no

45 Héctor Díaz Polanco, Elogio a la diversidad: Globalización, multiculturalismo y etNofagia (Siglo XXI, México) (2007). 
possibility of a constitutional state. Why is this so? Because citizens and social movements can permanently supervise, control, propose and demand that rights be guaranteed. The state's institutions and mechanisms of accountability cannot be trusted exclusively as the majority of these have been co-opted by institutionalized powers, as well as the powers that be. ${ }^{46}$ Citizens and social movements can prevent a chasm from forming between the government and the governed, and demand the guarantee of human rights. The traditional state and party system is decaying and obsolete, and has found an ally in transnational powers, preventing the full exercise of human rights.

\section{The Unsucaessful Efforts at Direct and Communitarian Democracy in the Recent Mexico Gity Constitution}

Some have praised Mexico City's Constitution, which was ratified by the Constitutional Assembly of Mexico City on the $31^{\text {st }}$ of January, 2017, and published in the National Official Gazette and the Federal District's Official Gazette $^{47}$ on February 5th of the same year, for its progressive nature. Others, including myself, have been critical of its shortcomings.

Article 22 of the Mexico City Constitution does not recognize Indigenous peoples, Indigenous residents of the city or Afro-Mexicans as part of the city's population - instead it is guided by an individualistic conception of population. Article 22, which refers to the population, does not acknowledge displaced peoples or migrants who are recognized in international law. These groups of people are mentioned in a separate part of the Constitution which does not focus on the city's population.

The drafters of Article 23, which focuses on the duties of citizens, refused to include the obligation to disobey laws that do not originate from democratic procedures or which do not respect human rights. The duty to disobey unjust laws disappeared from the final version of the Mexico City Constitution. An important proposal included accepting that citizens have a duty to obey just and democratic laws, as unjust regulations do not form part of the law. Civil disobedience, which is a democratic, liberal procedure with a long philosophical pedigree, was thus kept out of the Mexico City Constitution.

The important category of universal citizenship, which implies developing active citizenship from childhood and for every person in the world, was removed from Article 24. The assembly also refused to extend the right to vote to everyone 16 years of age or older, and it denied this same right, as well as

46 In Spanish, poderes fácticos refer to social actors who, despite not holding elected office of participating in one of the State's institutions, wield significant influence over political life through reserved domains of power. These may be companies, media outlets, religious organizations, lobbying groups, etcetera.

47 Mexico's Diario Oficial de la Federación and Mexico City's Diario Oficial. 
denying the right to run for office to those who have been accused of criminal charges but who are awaiting or standing trial, which goes against the presumption of innocence. In addition, the assembly refused to extend the vote to foreigners who have lived in Mexico City for more than two years. It also refused a provision that stipulated that no citizen can be detained or charged on the day before or the same day of the elections, except for those charged with a flagrant crime and, in such cases, authorities would take measures to allow the citizen to vote - this is a provision that already exists in the Constitution of the State of Chihuahua.

With regards to the citizens' right to propose legislative initiatives, the drafters refused to guarantee the right to any person to promote initiatives, which is a provision that is included in the Constitution of the State of Mexico. In this state, signatures equivalent to 0.13 percent of the 7.5 million names on electoral register are required for citizens to present an initiative, and initiatives are preferential if they include signatures equal to 0.25 percent of the electoral register. This lack of inclusion in the México City Constitution is especially disappointing for those of us who believe that citizen initiatives should always be preferred before those of the authorities.

The assembly also refused to include the right of citizens to reform the Constitution through referendums, and instead opted for a rule that requires the vote of two thirds of the local congress to achieve this objective. In the case of constitutional norms or constitutional laws, the referendum to adopt changes should have been mandatory, while in the case of general and abstract norms, the provision should have demanded that it be initiated with: a) signatures equivalent to 0.2 percent of the voter roll; b) a tenth of the votes in the local congress; or c) a tenth of the mayors. Referenda should have been included as part of reform procedures on every issue, with the exception of proposals that seek to curtail human rights. And yet, Article 25, Section C of the Constitution in fact raises the requirements for referendums and prohibits referendums in fiscal and penal matters.

The plebiscite, which is a form of consultation of public policies implemented by the local executive or mayor's offices, can be requested through the signatures of 0.4 percent of the electoral register. The local executive may also request a plebiscite, as may one third of congress or one third of mayors. These are excessive requirements, and the subject matter is limited because fiscal, tax and penal issues are exempted from this procedure.

The drafters did not wish to incorporate a proposal which stipulated that, with regards to decisions about the environment or historical and cultural heritage, and when dealing with (public or private) mega construction projects, consultations would be mandatory, binding and would not require presenting the signatures of citizens. The drafters also failed to accept consultation and other procedures to ensure consent from Indigenous peoples and Afro-Mexicans on constitutional, legislative and administrative norms, be prior, informed, mandatory, binding and effective. Nor did they accept that 
citizens have a right to seek consultations about any action or omission from the authorities. In the current text, according to Article 25, Section E, Clause 2, of the Mexico City Constitution, two percent of signatures from the electoral register in a given electoral demarcation are required in order to seek a citizen consultation, which would then be regulated by the law.

Popular consultations are a form of direct democracy that must be carried out exclusively on regular election days and require that two percent of the voter roll request its inclusion. Consultations exclude fiscal, taxation or penal issues.

According to the new Mexico City Constitution, citizens can revoke the mandate of elected representatives when at least 10 percent of the electoral register in the corresponding electoral circumscription so requests. But this request is only valid once at least half of the official's term has passed, and the results of the election are binding only if a 40 percent voter turnout threshold is met and if at least 60 percent of the votes cast were in favor of revoking the mandate. These are very strict regulations that effectively hinder the capacity to revoke the mandate of public officials.

In a participative democracy, the most important figure is that of participatory budgets. It never entails 100 percent of the budget. In the case of the Mexico City Constitution, this will be regulated by a secondary law passed in accordance with Article 26, Section B, Clause 2.

The Constitution of Mexico City stipulates in Section B of Article 35 that the justices of the Supreme Court of the city be designated by a two-thirds majority of the local congress from a shortlist of three candidates chosen by the judicial council. ${ }^{48}$ Some assembly members, including myself, argued that these justices should be elected by citizens without the possibility of reelection. Our proposal included a seven-year term, and it also set out that candidates to the position should satisfy the requisites included in Article 95 of Mexican Constitution, in addition to those of subsequent laws. The proposal established that prior to an election, candidates would undergo an exam that would be organized by the judicial council and held by a public university, under citizen control. The top three scorers on the exam would appear on the ballot. The election would occur without party meddling, and candidates would not carry out campaigns. It also proposed that in the cases where these candidates were aided by political parties, their candidacy would be canceled. They would be allotted time on radio and television to present their résumés, and proposals, and they would be elected as part of a larger electoral process held in the city. This proposal also included a call for the process to guarantee gender equality and representation for Indigenous peoples (natives of Mexico City and those who are not native to the city but reside there) and Afro-

\footnotetext{
48 The additional requirements were meant to be those derived from the ley orgánica which is a law that emanates directly from a constitutional provision.
} 
Mexicans. ${ }^{49}$ Nevertheless, our proposal for electing justices was not included in the constitution.

In the text as approved, there can be a challenge the constitutionality of a law or norm at a local judicial authority — an unelected constitutional court - as long as five thousand citizens petition for this. And in some cases, this can even result in the removal of the provision from the legal system.

The heads of constitutionally autonomous powers will be designated by a qualified majority of the local congress from among the nominees put forth by the citizen councils - according to Article 46, Section C, Subsection 3. This method will incentivize the distribution of quotas among the major political parties of the local congress. A better method would have included citizen selection, as per our proposal for a method of selecting supreme court justices so as to avoid the heads of these autonomous powers from acting as mere transmission belts on behalf of the largest parties, but rather acting with democratic legitimacy from the outset. ${ }^{50}$

Indigenous peoples native to Mexico City and who reside there - mentioned in Articles 57, 58 and 59 of the Mexico City Constitution- were not given full territorial autonomy, and their townships will not be constituted into a fourth level of territorial or functional circumscription. Nor will they be able to participate in consultations about reforms to the Constitution, consultations will be nonbinding, and the city's institutions will not be pluri-ethnic in their composition, which is particularly egregious in the case of mayors, congress, the cabinet or the Supreme Court of Justice, as this means that there will not be representatives of Indigenous peoples within these institutions. The consultation carried out among Indigenous peoples and Indigenous residents of the city for the ratification of the city's Constitution did not allow them to vote on the whole text of the Constitution, which was relevant to them in its entirety, rather it only allowed them to vote on the three articles mentioned above. ${ }^{51}$

A very important part of the Constitution deals with urban development. The Institute of Democratic Planning (IPD) is charged with the urban development and territorial management of the metropolis, but does not have constitutional autonomy form the city's government and its heads are not elected by popular vote. Instead, it will be under the control of the administration in

\footnotetext{
49 José María del Castillo Velasco, Apuntamientos para el estudio del derecho constitucional mexicano (copy, Miguel Ángel Porrúa, México 2007) (1879). Daniel Cosío Villegas, La constitución de 1857 y sus críticos (Fondo de Cultura Económica and Clío, México, 2007) (1957). Jeremy Waldron, The Dignity of Legislation (Cambridge University Press, 1999) (1995).

50 John M. Ackerman, Organismos autónomos y democracia. El caso de México 41 (UNAM-Siglo XXI, México) (2007).

51 Mario Maldonado Smith, Torres de babel. Estado, multiculturalismo y derechos humanos 127-195 (UNAM, México) (2015).
} 
power, and so particularly influenced by the head of government. ${ }^{52}$ According to Article 15, Section D of the Constitution, the Institute of Democratic Planning will be a decentralized office that will plan urban development for the city in 20-year timeframes, as well as preparing territorial management schemes with 15-year horizons. The city's urban development will depend on the Institute of Democratic Planning, which - although it is checked by congress in issues related to high-impact zoning and some other issues, ${ }^{53}$ lacks sufficient mechanisms of citizen control and accountability. This is in effect a technocracy, where some citizens will participate along with the private sector, without being subject to sufficient democratic controls, be they representative, direct or communitarian. Nevertheless, it will be charged with urban and territorial planning in Mexico City.

\section{Conclusions}

This critical review shows the political uses of the law, and the difficulties which critical and popular constitutional models and practices face in countries such as Mexico. The legitimacy deficits in Mexico's constitutional framework are evident given the impossibility to create advanced forms of democracy that are participatory, direct, deliberative and communitarian and that transcend the deficiencies of representative democracy.

The process of drafting Mexico City's recent Constitution, approved on January 31, 2017, demonstrates that a document of this nature needs the ongoing backing and participation of citizens. Unfortunately, during this political and legal process, most of the city's residents were oblivious to the activities of the local constitutional assembly. Mexico City's new Constitution includes some important innovations, such as: regulating urban development and land zoning; recognizing the right to the city; a recognition of the right to a vital minimum; the right to a dignified life and death; the right to use cannabis for medical and scientific purposes; reproductive and sexual rights; the right to care; the right to leisure; and labor rights for non-salaried workers, among others. It also recognizes, albeit in a limited way, some representative, direct and participatory democratic figures. It will have impact in the future because it does recognize, though in a restrictive manner, the rights of Indigenous peoples - those native to Mexico City and those who reside there - and it acknowledges the Afro-Mexican community. This document also grants a degree of independence for the judicial council from the President of the

52 Fefe de Gobierno or the head of government is the executive branch of Mexico City's government.

53 Enrique Provencio, Visión y proyecto de ciudad en la Constitución in Configuraciones. Aportes al debate constituyente de Ciudad de México 41 Revista de la Fundación Pereyra y del Instituto de Estudios para la transición democrática 94-105 (2016). 
Supreme Court of Mexico City. It designates a mandatory two percent of the city budget to fund science and technology. It forbids the privatization of water management, except for purification procedures. It suppresses legal exemptions for public servants. It creates a constitutional court dependent on the Supreme Court that will rule on issues to protect and restitute rights, as well as determining the constitutionality of general laws that the city and its authorities issue (although these issues can only be brought to this court in a way that favors elites). These and other innovations are certainly important, however, from my point of view, they fall short of the expectations of the residents of Mexico City, which is the most critical and progressive city in Mexico.

Mexico City's recently approved Constitution also includes neoliberal and technocratic provisions. It does not radically expand human rights nor does it impose strong limits and controls over public and economic powers. It does not commit to guaranteeing human, economic, social, cultural or environmental rights. It places obstacles to direct and participatory democratic methods. And although it recognizes the rights of Indigenous peoples, both natives and residents of the city, it does not provide sufficient and binding legal figures that allow them to oppose the decisions which affect them directly or indirectly. Real estate groups, on the other hand, have been given vast powers, and urban and territorial policy are concentrated in a technocratic office that is not under effective citizen control. 